\title{
Evaluasi Badan Perencanaan Pembangunan Daerah Dalam Rencana Tata Ruang Wilayah Perkotaan Di Kabupaten Karawang
}

\author{
Agnes Maulida Putri Pamungkas \\ Program Studi Ilmu Pemerintahan \\ Fakultas Ilmu Sosial dan Ilmu Politik \\ Universitas Singaperbangsa Karawang
}

\begin{abstract}
ABSTRAK
Kota merupakan pusat konsentrasi permukiman dan aktivitas penduduk. Sebagai tempat konsentrasi penduduk, maka kota menjadi pusat inovasi kehidupan perkotaan. kota sebagai jantung perekonomian nasional memiliki peran yang sangat besar bagi pembangunan. Untuk menghindari terjadinya masaiah-masalah perkotaan yang semakin rumit pada masa yang akan datang dan menghindari masalah-masalah perkotaan yang telah terjadi dimasa lampau, perlu dilakukan Evaluasi terhadap Rencana Tata Ruang Wilayah Terdahulu dan mengarahkan rencana untuk kedepan. Kabupaten Karawang sama halnya dengan kota-kota lain di Indonesia yang terus mengalami peningkatan jumlah penduduk. Penataan kota harus memperhatikan keseimbangan lingkungan dan kelayakan huni merupakan suatu persoalan yang harus segera ditangani dan dicarikan jalan keluarnya oleh Pemerintah Daerah Kabupaten Karawang.
\end{abstract}

\section{Kata Kunci : Evaluasi, Tata Ruang Wilayah, Perkotaan, Kabupaten Karawang}

\section{Pendahuluan}

Perkembangan masyarakat yang ada di dunia tumbuh dengan pesat dari waktu ke waktu. Jumlah penduduk di suatu negara yang terus meningkat akan menuntut pemerintah negaranya untuk selalu siap memenuhi segala sarana dan pemenuhan hidup rakyatnya baik yang di pedesaan maupun perkotaan. Suatu tata ruang yang dinamis tetap memelihara kelestarian kemampuan lingkungan hidup sesuai dengan pembangunan berwawasan lingkungan yang berlandaskan pada Wawasan Nusantara dan Ketahanan Nasional yang ada dalam Undang-Undang Nomor 26 Tahun 2007 tentang Penataan Ruang. Kota merupakan pusat konsentrasi permukiman dan aktivitas penduduk. Sebagai tempat konsentrasi penduduk, maka kota menjadi pusat inovasi kehidupan perkotaan. Kota berperan penting dan sangat dominan dalam penghidupan dan kehidupan warganya, dalam berbagai kegiatan ekonomi, sosial, politik dan tatanan budayanya.

Dalam memenuhi kebutuhan dasar itu, perlu penataan ruang dan wilayah perkotaan yang efektif dan bekelanjutan. Penataan ruang dan wilayah itu menjadi masalah umum yang terjadi di banyak kota besar dan metropolitan. Permasalahan tata ruang, tidak saja karena kota sejak awal telah dibangun dan bertumbuh secara alami, akan tetapi perkembangan kota yang mengalami pertumbuhan pesat, sering lebih cepat dari konsep tata ruang yang diundangkan karena cepatnya laju pembangunan di perkotaan. Untuk 
menghindari terjadinya masaiah-masalah perkotaan yang semakin rumit pada masa yang akan datang dan menghindari masalah-masalah perkotaan yang telah terjadi dimasa lampau, perlu dilakukan penilaian terhadap Rencana Terdahulu dan mengarahkan rencana untuk kedepan sesuai dengan arah pembangunan sekarang dengan dibuat pedoman pengaturan dan program-program pembangunan kota jangka panjang yang berupa Rencana Tata Ruang Wilayah (RTRW).

Kabupaten Karawang sama halnya dengan kota-kota lain di Indonesia yang terus mengalami peningkatan jumlah penduduk. Luas wilayah Kabupaten Karawang sebesar $1.753,27 \mathrm{~km} 2$ atau 3,73\% dari luas Provinsi Jawa Barat. Kabupaten Karawang merupakan salah satu Kabupaten dengan pertumbuhan penduduk yang pesat.

Kabupaten Karawang dengan jumlah laju pertumbuhan penduduk tidak dibarengi dengan rencana tata ruang wilayah yang ada, walaupun Kabupaten Karawang sudah memiliki Rencana Tata Ruang Wilayah namun masih ditemukan adanya masalah-masalah penataan wilayah perkotaan, seperti:

a. Terbatasnya lahan yang dapat dimanfaatkan untuk pembangunan wilayah perkotaan

b. Kurang maksimalnya penataan kawasan seperti zona industri, zona pertanian, serta zona pemukiman penduduk sehingga rentan terjadinya banjir

c. Aktivitas manusia dalam menciptakan ruang-ruang terbangun akhirnya sering mengakibatkan masalah dikemudian hari

Penataan kota harus memperhatikan keseimbangan lingkungan dan kelayakan huni merupakan suatu persoalan yang harus segera ditangani dan dicarikan jalan keluarnya oleh Pemerintah Daerah Kabupaten Karawang, sehingga kualitas penataan kota tersebut menjadi lebih baik, memenuhi syarat keindahan, kebersihan dan kesehatan.

\section{Tinjauan Pustaka}

\section{Pengertian Evaluasi}

Istilah evaluasi mempunyai arti yang berhubungan, masing-masing menunjukkan pada aplikasi beberapa skala nilai terhadap hasil kebijakan dan program. Secara umum istilah evaluasi dapat disamakan dengan penafsiran (approach), pemberian angka (rating), dan penilaian (assesment), kata-kata yang menyatakan untuk menganalisis suatu hasil kebijakan dalam arti satuan nilainya. Evaluasi berkenaan dengan produk informasi mengenai nilai atau manfaat suatu hasil kebijkan. Ketika hasil suatu kebijkaan pada kenyataannnya mempunyai nilai, hal ini karena hasil tersebut memberi sumbangan pada tujuan dan sasaran (Dunn, 2000).

\subsection{Fungsi-Fungsi Evaluasi Kebijakan Publik}

Menurut Samudra dan kawan-kawan dalam Nugroho (2003:186-187), evaluasi kebijakan publik memiliki empat fungsi, yaitu:

a. Eksplanasi. Melalui evaluasi dapat dipotret realitas pelaksanaan program dan dapat dibuat suatu generalisasi tentang pola-pola hubungan antar berbagai 
dimensi realitas yang diamatinya. Dari evaluasi ini evaluator dapat mengidentifikasi masalah, kondisi, dan aktor yang mendukung keberhasilan atau kegagalan program.

b. Kepatuhan. Melalui evaluasi dapat diketahui apakah tindakan yang dilakukan oleh para pelaku, baik birokrasi maupun pelaku lainya sesuai dengan standar dan prosedur yang ditetapkan oleh kebijakan.

c. Audit. Melalui evaluasi dapat diketahui, apakah output benar-benar sampai ke tangan kelompok sasaran kebijakan, atau justru ada kebocoran atau penyimpangan.

d. Akunting. Dengan evaluasi dapat diketahui apa akibat social ekonomi dari kebijakan tersebut.

Menurut Soeprapto (2000:60): Isu yang kritis dalam evaluasi dampak kebijakan adalah apakah suatu program telah telah menghasilkan efek yang lebih atau tidak yang terjadi secara alami meskipun tanpa intervensi atau dibandingkan dengan intervensi alternatif. Tujuan pokok penilaian dampak adalah untuk menafsirkan efek-efek yang menguntungkan atau hasil yang menguntungkan dari suatu intervensi. Rossi dan Freeman (dalam William Dunn, 2000: 36). Mendefinisikan penilaian atas dampak adalah untuk memperkirakan apakah intrvensi menghasilkan efek yang diharapkan atau tidak. Perkiraan seperti ini tidak menghasilkan jawaban yang pasti tapi hanya beberapa jawaban yang mungkin masuk akal.

Berdasarkan beberapa pengertian di atas maka dapat dinyatakan bahwa evaluasi sistematis kebijakan adalah aktivitas untuk menjawab pertanyaanpertanyaan seperti apakah kebijakan yang dijalankan mencapai tujuan sebagaimana yang telah ditetapkan sebelumnya, berapa biaya yang di keluarkan serta keuntungan apa yang didapat, siapa yang menerima keuntungan dari program kebijakan yang telah dijalankan oleh organisasi.

2. Pengertian Rencana Tata Ruang Wilayah

Menurut Daud Silalahi $(2001,82)$, yang mengemukakan bahwa rencana tata ruang wilayah merupakan suatu pengertian yang secara eksplisit tersirat cakupan yang luas mengandung arti bahwa :

a. Seluruh wilayah Indonesia adalah kesatuan tanah air dari seluruh rakyat Indonesia yang bersatu sebagai bangsa Indonesia.

b. Seluruh bumi, air dan ruang angkasa termasuk kekayaan alam yang terkandung didalamnya sebagai karunia Tuhan Yang Maha Esa merupakan kekayaan nasional

c. Hubungan antara bangsa Indonesia dan bumi, air serta ruang angkasa termasuk bagian hubungan yang bersifat abadi.

d. Dalam pengertian bumi, selain permukaan bumi termasuk pula tubuh bumi dibawahnya serta yang berada dibawah air.

e. Dalam pengertian air termasuk baik perairan pedalaman maupun laut wilayah Indonesia.

f. Yang dimaksud dengan ruang angkasa ialah ruang di atas bumi dan air adalah yang berada didalam bumi.

Keenam point tersebut di atas secara tersirat mengandung pemaknaan terhadap ruang suatu wilayah yang perlu ditata khususnya yang berkaitan dengan bumi, air dan ruang angkasa serta kekayaan yang terdapat dalam suatu wilayah. Menurut Solihin (2004, 
18 ) memberikan pengertian rencana tata ruang wilayah adalah Mengatur, mengelola, menangani, mempotensikan segala hal yang ada di atas bumi, air dan ruang angkasa untuk digunakan bagi kesejahteraan manusia yang tinggal dalam ruang tersebut untuk memenuhi kepentingannya sesuai dengan kaidah-kaidah hukum yang mengatur penggunaan ruang.

Dalam Peraturan Daerah Kabupaten Karawang Nomor 2 Tahun 2013 Tentang Rencana Tata Ruang Wilayah Kabupaten Karawang Tahun 2011 - 2031 memberikan pengertian bahwa: Rencana tata ruang wilayah adalah suatu tindakan dalam mengelola dan menata suatu ruangan berdasarkan pemanfaatan pengelolaan sumber daya alam yang beraneka ragam di dataran, di lautan dan di udara, yang perlu dilakukan secara terkoordinasi dan terpadu dalam pola pembangunan berkelanjutan dengan mengembangkan tata ruang dalam satu kesatuan tata lingkungan yang dinamis serta tetap terpeliharanya kelestarian kemampuan lingkungan hidup sesuai dengan pembangunan berwawasan lingkungan, yang menjadikan rencana tata ruang wilayah menjadi penting dan utama, sehingga diberikan adanya pengertian yang dapat dibedakan menurut peraturan daerah pengertian ruang, tata ruang, rencana tata ruang wilayah, rencana tata ruang dan wilayah.

Penjelasan uraian tersebut di atas maka dapat dibedakan pengertian yang memberikan keutuhan atas pengertian rencana tata ruang wilayah yang dikemukakan oleh Sadli Samad (2003, 42 )yaitu sebagai berikut:

a. Ruang adalah wadah yang meliputi ruang daratan, ruang lautan dan makhluk lainnya hidup dan melakukan kegiatan serta memelihara kelangsungan hidupnya

b. Tata ruang adalah wujud struktural dan pola pemanfaatan ruang baik direncanakan maupun tidak

c. Rencana tata ruang wilayah adalah proses perencanaan tata ruang, pemanfaatan ruang dan pengendalian pemanfaatan ruang,

d. Rencana tata ruang adalah hasil perencanaan tata ruang dan,

e. Wilayah adalah ruang yang merupakan kesatuan geografis beserta segenap unsur terkait padanya ruang batas dan sistem ditentukan berdasarkan aspek administrasi dan atau aspek fungsional.

Atas uraian dan tinjauan yang dikemukakan di atas, maka dapat diambil suatu kesimpulan bahwa rencana tata ruang wilayah diartikan sebagai bentuk perumusan kebijakan pokok dalam memanfaatkan ruang dalam suatu wilayah yang mewujudkan keterpaduan, keterkaitan dan keseimbangan perkembangan antara wilayah serta keserasian antara sektor dalam mengeksiskan pentingnya rencana tata ruang wilayah yang diterapkan di Kabupaten Karawang 


\section{Metode Penelitian}

Dalam penelitian ini, peneliti menggunakan metode deskriptif dengan pendekatan penelitian Kualitatif. Dilakukan dengan cara pengamatan langsung dan wawancara mendalam dengan informan yang telah ditentukan. Kemudian, data yang ditemukan dari hasil wawancara dan pengamatan tersebut akan dianalisis secara kualitatif. Sugiyono (2017:9) menjelaskan pengertian tentang metode penelitian kualitatif diartikan sebagai metode penelitian yang berlandaskan pada filsafat pospositivisme, digunakan untuk meneliti pada kondisi objek yang alamiah, (sebagai lawannya adalah eksperimen) dimana peneliti adalah sebagai instrumen kunci, teknik pengumpulan data dilakukan secara triangulasi (gabungan), analisis data bersifat indukti/kualitatif, dan hasil penelitian kualitatif lebih menekankan makna daripada generalisasi.

Peneliti menggunakan sumber primer dan sumber sekunder karena dalam mengolah informasi peneliti mengumpulkan data-data yang diperlukan langsung dari objek pertama yang akan diteliti yaitu Badan Perencanaan Pembangunan Kabupaten Karawang. dan peneliti menggunakan data sekunder karena peneliti mengumpulkan informasi dari data yang telah diolah oleh pihak lain, yaitu informasi dari literasi-literasi buku, artikel, jurnal atau berita media online maupun cetak mengenai konsep evaluasi organisasi serta masalah-masalah Rencana tata ruang wilayah perkotaan Kabupaten Karawang.

Peneliti menggunakan bermacam-macam teknik pengumpulan data, yaitu observasi, wawancara, dokumentasi, dan gabungan atau triangulasi.

\section{Pembahasan}

1. Efektivitas (effectiveness) Dalam Rencana Tata Ruang Wilayah Perkotaan Di Kabupaten Karawang.

Efektivitas (effectiveness) berkenaan dengan apakah suatu alternatif mencapai hasil (akibat) yang diharapkan, atau mencapai tujuan dari diadakannya tindakan. Efektivitas, yang secara dekat berhubungan dengan rasionalitas teknis, selalu diukur dari unit produk atau layanan atau nilai moneternya. Efektivitas dalam penelitian ini, membahas mengenai Rencana Tata Ruang Wilayah Perkotaan Kabupaten Karawang. efektifitas yang dilakukan Badan Perencanaan dan Pembangunan Kabupaten Karawang masih banyak kendala dalam melakukan evaluasi, evaluasi yang baik harus terencana, terprogram serta dapat dirasakan oleh semua masyarakat. Dalam evaluasi Rencana Tata Ruang Wilayah Perkotaan di Kabupaten Karawang, masih terus mengalami perubahan-perubahan tiap tahunnya mengikuti perkembangan yang ada di Kabupaten Karawang.

2. Efisiensi (efficiency) Dalam Rencana Tata Ruang Wilayah Perkotaan Di Kabupaten Karawang. 
Efisiensi (efficiency) berkenaan dengan jumlah usaha yang diperlukan untuk menghasilkan tingkat efektivitas tertentu. Efisiensi, yang merupakan sinonim dari rasionalitas ekonomi, adalah merupakan hubungan antara efektivitas dan usaha, yang terakhir umumnya diukur dari ongkos moneter. Kebijakan yang mencapai efektivitas tertinggi dengan biaya terkecil dinamakan efisiensi. Efisiensi pada penelitian ini mengarah pada jumlah sumber daya manusia dan sumber daya finansial yang dikeluarkan untuk melaksanakan program. efisiensi dalam evaluasi yang dilakukan Badan Perencanaan dan Pembangunan Daerah Perkotaan Kabupaten Karawang masih terdapat kendala-kendala dalam pelaksanaanya. Belum efisiensinya Evaluasi Badan Perencanaan dan Pembangunan Kabupaten Karawang dikarenakan dalam pelaksanaanya belum memenuhi syarat-syarat kelayakan yang baik. Setiap pembangunan harus melalui perencanaan yang baik dan matang sehingga hasil yang didapat maksimal, selain itu sumberdaya yang ada di Bappeda belum terpenuhi dengan kualitasnya, dengan pembangunan yang terus meningkat dan cepat membutuhkan sumberdaya manusia dan modal yang besar untuk merealisasikannya.

\section{Kecukupan (adequacy) Dalam Rencana Tata Ruang Wilayah Perkotaan Di} Kabupaten Karawang.

Kecukupan (adequacy) berkenaan dengan seberapa jauh suatu tingkat efektivitas memuaskan kebutuhan, nilai, atau kesempatan yang menumbuhkan adanya masalah. Kriteria kecukupan menekankan pada kuatnya hubungan antara alternatif kebijakan dan hasil yang diharapkan. Kecukupan pada penelitian ini mengarah pada pencapaian program dan kaitannya dengan pemecahan masalah, dan apakah alternatif pemberian bantuan telah cukup untuk mengatasi kebutuhan, nilai, atau kesempatan yang menumbuhkan adanya masalah Rencana Tata Ruang Wilayah Perkotaan Kabupaten Karawang. kecukupan dalam evaluasi yang dilakaukan oleh Badan Perencanaan dan Pembangunan Kabupaten Karawang masih belum melibatkan masyarakat dalam membuat suatu program yang berkelanjutan. Masih banyak masyarakat yang belum tahu evaluasi yang dilakukan oleh Badan Perencanaan dan Pembangunan Kabupaten Karawang itu seperti apa. Pembangunan yang baik harus ada peran serta masyarakat dalam prosesnya, sehingga masyarakat menjadi sadar dan mengerti perencanaan dan pembangunan yang dilakukan pemerintah Kabuparen Karawang.

4. Kesamaan (equity) Dalam Rencana Tata Ruang Wilayah Perkotaan Di Kabupaten Karawang.

Kriteria kesamaan/perataan (equity) erat berhubungan dengan rasionalitas legal dan sosial dan menunjuk pada distribusi akibat dan usaha antara kelompok-kelompok yang 
berbeda dalam masyarakat. Kriteria kesamaan erat berhubungan dengan konsepsi yang saling bersaing, yaitu keadilan atau kewajaran dan terhadap konflik etis sekitar dasar yang memadai untuk mendistribusikan risorsis dalam masyarakat. Perataan dalam penelitian ini membahas tentang distribusi informasi program (sosialisasi program) dan distribusi program kepada kelompok sasaran. Dari penelitian diatas dapat digambarkan bahwa sosialisasi serta distribusi program kerja yang dilakukan oleh Badan Perencanaan dan Pembangunan Kabupaten Karawang dalam melakukan evaluasi wilayah perkotaan masih belum optimal, belum semua masyakat dapat informasi yang berkaitan dengan Rencana Tata Ruang Wilayah Perkotaan Kabupaten Karawang, selain itu melalui pengamatan yang ada, perencanaan dan pembangunan masih terpusat di wilayah karawang kota, pada dasarnya pembangunan suatu wilayah harus melihat dari segi jumlah penduduk di wilayah tersebut. Tapi dalam pelaksanaanya pembangunan yang dilakukan masih belum optimal banyak sekali perencanaan-perencaan yang tidak sesuai dengan waktunya serta pembangunannya yang terlalu terburu-buru sehingga hasil yang didapat kurang maksimal.

5. Responsivitas (responsiveness) Dalam Rencana Tata Ruang Wilayah Perkotaan Di Kabupaten Karawang.

Responsivitas (responsiveness) berkenaan dengan seberapa jauh kebijakan atau program dapat memuaskan kebutuhan, preferensi, atau nilai kelompok-kelompok masyarakat di Kabupaten Karawang. Dari hasil wawancara dengan para narasumber menerangkan responsivitas terkait Rencana Tata Ruang Wilayah Kabupaten Karawang harus mengacu kepada rencana strategis yang dibuat sebelumnya. Dan akan terus mengalami pembaharuan-pembaharuan sesuai dengan kebutuhan yang ada. Serta sosialiasi terkait rencana tata ruang wilayah perkotaan Kabupaten Karawang masih belum optimal dalam pelaksanaanya. Sosialisasi yang baik harus intens dan bekelanjutan sehingga hasil yang dilakukan oleh Badan Perencanaan dan Pembangunan Daerah Kabupaten Karawang dapat secara optimal.

6. Ketepatan (appropriateness) Dalam Rencana Tata Ruang Wilayah Perkotaan Di Kabupaten Karawang.

Kriteria ketepatan (appropriateness) secara dekat berhubungan dengan rasionalitas substantif, karena pertanyaan tentang ketepatan kebijakan tidak berkenaan dengan satuan kriteria individu tetapi dua atau lebih kriteria secara bersama-sama. Ketepatan merujuk pada nilai atau harga dari tujuan program dan kepada kuatnya asumsi yang melandasi tujuan-tujuan tersebut. Pada penelitian ini, ketepatan membahas mengenai ketepatan waktu dan ketepatan program dalam menyelesaikan masalah Rencana Tata Ruang Wilayah Perkotaan di Kabupaten Karawang. Dari penelitian diatas terkait dengan ketepatan yang dilakukan oleh Badan Perencanaan dan Pembangunan Daerah Kabupaten Karawang belum optimal banyak kendala dalam pelaksanaanya, banyak 
pekerjaan-pekerjaan yang tidak tepat waktu dalam pekerjaanya serta dana yang digunakan masih minim, kendala-kendala tersebut dapat menghambat pengerjaan yang seharusnya sesuai dengan rencana yang telah dibuat.

\section{Kesimpulan dan Saran}

1. Kesimpulan

Berdasarkan hasil penelitian dan pembanhasan masalah penelitian, maka peneliti melakukan penyimpulan hasil penelitian yang telah dilakukan mengenai Evaluasi Badan Perencanaan Pembangunan Daerah Dalam Rencana Tata Ruang Wilayah Perkotaan Di Kabupaten Karawang

a. Efektifitas yang dilakukan Badan Perencanaan dan Pembangunan Kabupaten Karawang masih banyak kendala dalam melakukan evaluasi, evaluasi yang baik harus terencana, terprogram serta dapat dirasakan oleh semua masyarakat. Dalam evaluasi Rencana Tata Ruang Wilayah Perkotaan di Kabupaten Karawang, masih terus mengalami perubahan-perubahan tiap tahunnya mengikuti perkembangan yang ada di Kabupaten Karawang.

b. Efisiensi dalam evaluasi yang dilakukan Badan Perencanaan dan Pembangunan Daerah Perkotaan Kabupaten Karawang masih terdapat kendala-kendala dalam pelaksanaanya. Belum efisiensinya Evaluasi Badan Perencanaan dan Pembangunan Kabupaten Karawang dikarenakan dalam pelaksanaanya belum memenuhi syaratsyarat kelayakan yang baik. Setiap pembangunan harus melalui perencanaan yang baik dan matang sehingga hasil yang didapat maksimal, selain itu sumberdaya yang ada di Bappeda belum terpenuhi dengan kualitasnya, dengan pembangunan yang terus meningkat dan cepat membutuhkan sumberdaya manusia dan modal yang besar untuk merealisasikannya.

c. Kecukupan dalam evaluasi yang dilakaukan oleh Badan Perencanaan dan Pembangunan Kabupaten Karawang masih belum melibatkan masyarakat dalam membuat suatu program yang berkelanjutan. Masih banyak masyarakat yang belum tahu evaluasi yang dilakukan oleh Badan Perencanaan dan Pembangunan Kabupaten Karawang itu seperti apa. Pembangunan yang baik harus ada peran serta masyarakat dalam prosesnya, sehingga masyarakat menjadi sadar dan mengerti perencanaan dan pembangunan yang dilakukan pemerintah Kabuparen Karawang.

d. Kesamaan dalam Rencana Tata Ruang Wilayah Perkotaan di Kabupaten Karawang, sosialisasi serta distribusi program kerja yang dilakukan oleh Badan Perencanaan dan Pembangunan Kabupaten Karawang dalam melakukan evaluasi wilayah perkotaan masih belum optimal, belum semua masyakat dapat informasi yang berkaitan dengan Rencana Tata Ruang Wilayah Perkotaan Kabupaten Karawang, selain itu melalui pengamatan yang ada, perencanaan dan pembangunan masih terpusat di wilayah karawang kota, pada dasarnya pembangunan suatu wilayah harus melihat dari segi jumlah penduduk di wilayah tersebut. Tapi dalam pelaksanaanya pembangunan yang dilakukan masih belum optimal banyak sekali perencanaanperencaan yang tidak sesuai dengan waktunya serta pembangunannya

e. yang terlalu terburu-buru sehingga hasil yang didapat kurang maksimal.Responsivitas terkait Rencana Tata Ruang Wilayah Kabupaten Karawang harus mengacu kepada rencana strategis yang dibuat sebelumnya. Dan akan terus mengalami pembaharuan-pembaharuan sesuai dengan kebutuhan yang ada. Serta sosialiasi terkait rencana tata ruang wilayah perkotaan Kabupaten Karawang masih belum optimal dalam pelaksanaanya. Sosialisasi yang baik harus intens dan bekelanjutan sehingga hasil yang dilakukan oleh Badan Perencanaan dan Pembangunan Daerah Kabupaten Karawang dapat secara optimal. 
f. Ketepatan yang dilakukan oleh Badan Perencanaan dan Pembangunan Daerah Kabupaten Karawang belum optimal banyak kendala dalam pelaksanaanya, banyak pekerjaan-pekerjaan yang tidak tepat waktu dalam pekerjaanya serta dana yang digunakan masih minim, kendala-kendala tersebut dapat menghambat pengerjaan yang seharusnya sesuai dengan rencana yang telah dibuat.

2. Saran

Berdasarkan hasil penenlian dan kesimpulan yang telah peneliti paparkan di atas maka peneliti mencoba memberikan saran terhadap hasil penelitian agar dapat membantu para pelaksana kebijakan dalam menjalankan kegiatan Perencanaan Pembangunan Daerah Dalam Rencana Tata Ruang Wilayah Perkotaan Di Kabupaten Karawang Sesuai dengan tujuan program yang telah di gariskan sebagai berikut:

1. Melakukan perencanaan dan pembangunan yang telah ditetapkan secara intens dan terarah. Mekaksimalkan peran dari lembaga-lembaga dinas terkait secara bersinergi, upaya ini agar adanya peningkatan kualitas perencanaan dan penyelengaraan pembangunan wilayah perkotaan melalui peningkatan kapasitas dan kordinasi berbagai elemen lembaga kepentingan

2. Harus membuat perencanaan-perencanaan yang matang dan berkelanjutan sehingga pelaksanaan perencanaan dan pembangunan wilayah perkotaan tertata dengan baik dan efisien, serta harus mengoptimalkan sumber-sumber yang ada di Kabupaten Karawang secara optimal.

3. Memberikan edukasi-edukasi kepada masyarakat terkait pembangunanpembangunan yang ada di wilayah Kabupaten Karawang, sehingga masyarakat turut adil dalam pemajuan wilayahnya.

4. Sosialisasi yang dilakukan harus mengedepankan prinsip sesamaan kesetiap masyarakat di Kabupaten Karawang serta program-program yang dibuat oleh Badan Perencanaan dan Pembangunan Kabupaten Karawang harus dirasakan oleh semua lapisan masyarakat dan dapat dirasakan oleh semua masyarakat.

5. Melakukan upaya-upaya pendataan masyarakat dengan memaksimalkan peran RT/RW untuk memberikan arahan serta sosialisasi dalam menentukan kegiatan pembangunan serta melakukan musyawarah untuk mengatasi permasalahan dan menemukan solusi bersama-sama.

6. Membuat schedule yang matang dalam perencanaan dan terus melakukan upaya monitoring terhadap program-program yang dibuat dalam pembangunan wilayah perkotaan di Kabupaten Karawang.

\section{DAFTAR PUSTAKA}

\section{Buku}

Daud silalahi, hukum lingkungan, dalam sistem penegakan hukum lingkungan di Indonesia, alumni, 2001, hlm. 82

Dunn, William N. 2005. Pengantar Analisis Kebijakan Publik Edisi Kedua. Yogyakarta: Gadjah Mada University Press. 
Nugroho, Riant. 2009. Public Policy Dinamika Kebijakan-Analisis Kebijakan Manajemen Kebijakan. Jakarta: PT Elex Media Komputindo.

Nurhadi, rencana tata ruang wilayah perkotaan, tarsito, 2002, hlm. 70

Sadli samad, hukum rencana tata ruang wilayah, gramedia pustaka, 2003, hlm. 42

Siagian, Sondang P. 2012. Administrasi Pembangunan Konsep, Dimensi, dan Strateginya. Jakarta: PT Bumi Aksara.

Solihin, pengaturan hukum rencana tata ruang wilayah dan interior perkotaan, gramedia pustaka, 2004, hlm. 18

Sugianto, teori-teori hukum tata ruang, rajawali press, 2004, hlm. 82

Sugiyono, 2011, Metode Penelitian Kuantitatif, Kualitatif, dan R\& D. Bandung : Alfabeta

Winarno, Budi. 2012. Kebijakan Publik: Teori, Proses, dan Studi Kasus. Edisi dan Revisi Terbaru. Jakarta : PT. Buku Seru CAPS

\section{Dokumen}

Badan Pusat Statistik Kabupaten Karawang 2017

Undang-Undang Nomor 26 Tahun 2007 tentang Penataan Ruang

Peraturan Daerah Kabupaten Karawang Nomor 2 Tahun 2013 Tentang Rencana Tata Ruang Wilayah Kabupaten Karawang Tahun 2011-2031

Rencana Tata Ruang Wilayah Kabupaten Karawang 